\title{
PROYECTO EUROPEO \\ "JUSTICIA, DERECHOS Y \\ PARTICIPACIÓN DE LAS PERSONAS \\ CON DISCAPACIDAD INTELECTUAL"
}

\author{
MARÍA TERESA CASADO \\ Técnico Responsable del Programa de Reclusos y Ex-reclusos. FEAPS (Confederación \\ española de organizaciones en favor de las personas con discapacidad intelectual).
}

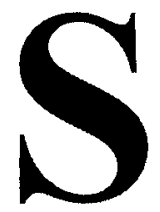

egún recoge la convocatoria de propuesta relativa a proyectos de cooperación e intercambio transnacional para combatir la exclusión social (DOCE 2002/C 98/10 de 23 de abril de 2002) y conforme a lo dispuesto en el Tratado de Amsterdam, la Comunidad Europea debe adoptar medidas para fomentar la cooperación en la lucha contra la exclusión social.

Las conclusiones del Consejo Europeo de Lisboa recogen que "las políticas para combatir la exclusión social deberían basarse en un método abierto de coordinación que combine los planes de acción nacionales y una iniciativa de la Comisión para la cooperación en este ámbito...". A propuesta de la Comisión, el Parlamento Europeo y el Consejo acordaron establecer un programa de acción comunitaria de cinco años de duración (2002 a 2006) para fomentar la cooperación entre los Estados miembros en la lucha contra la exclusión social.

En este marco, la Comisión Europea hizo pública dicha convocatoria que es el objeto de la Fase I del programa de intercambio transnacional.

Inclusion Europe, Asociación Europea de Organizaciones a favor de las Personas con Discapacidad Intelectual y sus Familias, consideró importante presentar un proyecto a esta convocatoria partiendo de la premisa de que la Unión Europea y sus Estados Miembros deben asegurar que todas las personas sean tratadas de un modo igual con las mismas oportunidades de participar en la sociedad. Esto no resulta fácil con el actual sistema judicial y su puesta en práctica resulta difícil, si no imposible, para que las Personas con Discapacidad Intelectual puedan ejercitar sus derechos.

Los socios parte del proyecto son:

- Inclusion Europe 
- Lebenshilfe, Alemania

- UNAPEI Francia

- Conseil Départemental de l'Accès au Droit de Paris, France

- Federatie van Ouderverenigingen, Holanda

- PAPMH, Polonia

- Oficina del Comisario para la Protección de los Derechos Civiles en Polonia

- FEAPS, Confederación Española de Organizaciones en favor de las Personas con Discapacidad Intelectual.

- Universidad de Alicante.

El proyecto ha pretendido analizar cómo mejorar el acceso a la Justicia de las personas con discapacidad intelectual en el marco de las regulaciones legales actuales especialmente en estas tres áreas:

Los procedimientos de incapacitación legal privan a muchas personas con discapacidad intelectual al acceso a la justicia y a la posibilidad de luchar por sus derechos. En muchos países de la Unión Europea y países candidatos, la incapacitación legal se produce en áreas en las que la persona es capaz de manejarse perfectamente.

El derecho legal al apoyo y a los servicios para las personas con discapacidad intelectual es muy diferente en cada país. Hay muchas áreas en las que no hay un derecho legal a los servicios para que una persona esté incluida en la sociedad.

Los procesos legales a menudo hacen imposible que las personas con discapacidad intelectual defiendan sus derechos debido a su incapacidad o la no existencia de apoyos legales adecuados.

Los objetivos propuestos para esta Fase I han sido:

1. El desarrollo de un inventario de buenas prácticas, conocimiento de las políticas institucionales para la mejora del acceso a la justicia y el ejercicio de los derechos de las Personas con Discapacidad Intelectual.

Los países socios en el proyecto han realizado un estudio, todavía en curso, que ofrecerá una visión de conjunto e impresiones sobre las tan dispares situaciones que se dan en los diferentes países europeos en relación a este tema.

Esto se ha llevado a cabo a través de un cuestionario que ha sido enviado a todos los países miembros de Inclusión Europe y países candidatos. En el caso de FEAPS (España), el documento ha sido cumplimentado por expertos en el campo de la Justicia, Servicios, Capacidad legal y Tutela.

El resultado se traducirá en un documento que será publicado y que 
compilará este conocimiento base con las experiencias e investigaciones para el futuro programa de trabajo del proyecto (Fase II).

2. Analizar el impacto de la existencia de Planes Nacionales de Acción Social para las Personas con Discapacidad Intelectual, en colaboración con las propias Personas con Discapacidad Intelectual, organizaciones de discapacidad y autoridades nacionales.

Los Planes Nacionales de Acción Social se han desarrollado con una participación mínima de las Personas con Discapacidad Intelectual y por ello no siempre reflejan sus necesidades en el avance de la inclusión social de este colectivo.

El proyecto ha trabajado con los grupos de autogestores (Personas con Discapacidad Intelectual que hablan por sí mismas) de los países socios los aspectos que deberían de contemplarse en el nuevo Plan Nacional de Acción Social y que les afectan directamente. En el caso de España, FEAPS envió estas sugerencias al IMSERSO para que fueran tenidas en cuenta en la elaboración del nuevo Plan Nacional de Acción Social (2003-2005).

3. Ampliar el partenariado del proyecto para la Fase II incluyendo más socios, medios de comunicación, etc.

4. Desarrollar un programa de trabajo de 2 años para la fase II que se centrará en el acceso a la justicia y ejercicio de los derechos.

Los objetivos descritos en los puntos 3 y 4 se están trabajando en estos momentos.

La Fase I del proyecto finalizará en una Conferencia Europea en Bruselas durante el último trimestre del año en la que se presentarán los resultados del proyecto y la continuación para la Fase II.

\section{INCLUSION EUROPE}

\section{RESPECT, SOLIDARITY AND INCLUSION}

Inclusion Europe is a non-profit organisation. We campaign for the rights and interests of people with intellectual disability and their families. Our members are national organisations from 33 countries in Europe.

People with intellectual disability are citizens of their country. They have an equal right to be included in society, whatever the level of their disability. They want rights, not favours.

People with intellectual disability have many gifts and abilities. They 
also have special needs. They need a choice of services to support their needs.

Inclusion Europe focuses on three main policy areas:

- Human Rights for people with intellectual disability

- Inclusion in society

- Non-discrimination

Inclusion Europe co-ordinates activities in many European countries, including projects, conferences, working groups and exchange meetings. It responds to European political proposals and provides information about the needs of people with intellectual disability. Inclusion Europe advises the European Commission and members of the European Parliament on disability issues.

Inclusion Europe coordinates projects that help the organisation and its partners develop ideas, strategies or that aims to raise awareness about the rights and needs of people with intellectual disability and their families. These projects concern various issues, such as the protection of human rights, the rights of people with intellectual disability as consumers, the social inclusion, the access to justice, etc. We are very keen to make information available to all of member, disabled or not. Therefore most of our projects have an accessibility component. We are eager to develop easy-to-read material, printed or accessible on the web. All information available in easy-to-read is marked with a specific logo.

2003 is the European Year of People with disabilities. Inclusion Europe has launched 2 initiatives to celebrate the year and raise awareness of the general public and the decision makers. In collaboration with our member societies in Europe we have organised a travelling art exhibition "Me, Blue and You ... against discrimination". 50 paintings by artists with intellectual disability toured Europe carrying a message of non-discrimination. Postcards were printed and sent to decision makers at national and European levels. The exhibition is a big success and we have very good report on the press.

We also decided to develop an accessible website. The website is launched and you can visit it on www.inclusive-europe-2003.org. The website has four levels of navigation allowing people with intellectual disability, family members of professionals to find information about the European Year and our main message against discrimination. This structure of the website will be implemented to our main information website soon.

For further information: Inclusion Europe, tel: $+32-2-502.28 .15$, fax: +32-2-502.80.10, e-mail: information@inclusion-europe.org. 